\title{
DIAGNÓSTICO PRELIMINAR DA SUPRESSÃO DE ESPÉCIES RECURSAIS NO NOVO CÓDIGO DE PROCESSO CIVIL
}

\section{PRELIMINARY DIAGNOSIS ABOUT THE APPEAL'S SUPPRESSION IN THE BRAZILIAN NEW CODE OF CIVIL PROCEDURE}

\author{
Diego Souza Merigueti ${ }^{1}$
}

\begin{abstract}
RESUMO
$\mathrm{O}$ fenômeno da morosidade no sistema judicial revela um atentado à própria justiça. Nesse sentido, o presente artigo tem por finalidade analisar a supressão de espécies recursais no novo Código de Processo Civil como meio apto a atingir o escopo de conferir maior celeridade à prestação da tutela jurisdicional no Brasil. No diagnóstico aqui proposto, serão apresentadas eventuais consequências jurídicas práticas decorrentes tanto da limitação das hipóteses de cabimento do Agravo de Instrumento quanto da abolição do Agravo Retido e dos Embargos Infringentes no diploma processual recém sancionado. Desdobrando a referida análise, destaca-se o movimento contemporâneo de realizar, na legislação processual, os valores e garantias constitucionais, dentre eles a razoável duração do processo. O texto foi produzido mediante análise de conceitos e consulta a obras, nacionais e estrangeiras, de autores de reconhecida contribuição para matéria, bem como por meio do estudo da nova legislação processual, tratando-se, pois, de uma revisão bibliográfica e de uma análise qualitativa.
\end{abstract}

Palavras-chave: Direito processual civil, Celeridade, Recursos, Novo código de processo civil

\begin{abstract}
The phenomenon of sluggishness in the judicial system reveals an attack to justice. In this purpose, this article aims to analyze the appeal's suppression in the brazilian new Code of Civil Procedure, as a way able to reach the scope of giving celerity to the jurisdictional protection in Brazil. At the diagnosis proposed, it will be presented possible legal consequences arising from the limitation of the "Agravo de Instrumento" and from the abolition of both "Agravo Retido" and "Embargos Infringentes" in the procedural diploma newly sanctioned. Unfolding this analysis, it is worth highlighting the contemporary movement to perform constitutional values and guarantees in procedural legislation, including the reasonable duration of the proceeding. This paper was produced by analyzing concepts and in consultation to national and foreing books, from authors of recognized contribution to the field, as well as through the study of the new procedural law, why it is therefore a literature review and a qualitative analysis.
\end{abstract}

Keywords: Civil procedural law, Celerity, Appeals, Brazilian new code of civil procedure

\footnotetext{
${ }^{1}$ Mestrando em Direito pela Universidade Federal do Espírito Santo - UFES, Espírito Santo, (Brasil). E-mail: diegosmerigueti@gmail.com
} 



\section{INTRODUÇÃO}

A morosidade na prestação da tutela jurisdicional tem se revelado, ao longo dos anos, um problema que atinge e preocupa não só os operadores do Direito, como também os próprios jurisdicionados, criando um ambiente propício ao aumento da desconfiança e do desprestígio do Estado como agente pacificador de conflitos sociais.

Nessa medida, é crescente o movimento em busca da realização concreta, nas legislações infraconstitucionais, dos valores e das garantias constitucionalmente asseguradas, sobretudo a que garante o direito de todos a uma duração razoável do processo, máxima expressamente assegurada na Carta Magna de 1988 no título dedicado aos direitos e garantias fundamentais.

O direito processual civil brasileiro, nesse processo evolutivo, passou por sucessivas reformas visando a atender o anseio por uma prestação jurisdicional mais célere, tendo o Código de Processo Civil de 1973, ao longo de sua existência, sofrido sucessivas reformas no afã de se adaptar aos novos paradigmas.

Embalado por este movimento, o novo Código de Processo Civil recéms ancionado (Lei $n^{\circ} 13.105$, de 16 de março de 2015) estabelece um liame entre a legislação processual e as garantias constitucionais, em que se escorou. Por esta razão, o novo diploma de ritos adotou diversas medidas em busca da celeridade, inclusive reduzindo hipóteses de cabimento de recursos ou, até mesmo, abolindo certas espécies recursais.

O presente artigo é, portanto, um convite a uma reflexão crítica e avaliativa desta estratégia legislativa que lançou mão da supressão de recursos como instrumento hábil e adequado ao combate da morosidade da prestação jurisdicional brasileira.

Noutro giro, a obra representa também um diagnóstico preliminar (eis que não é possível prever, concretamente, de que maneira se dará a operação das alterações na prática forense a partir da vigência do novo caderno processual) dos eventuais efeitos danosos à marcha processual e ao volume de processos.

Para responder a estas indagações, o estudo aqui proposto, sem a pretensão de ser exauriente, examinará, especificamente, a limitação das hipóteses de cabimento do Agravo de 
Instrumento e a extinção do Agravo Retido e dos Embargos Infringentes e apresentará suas eventuais consequências.

\section{A BUSCA PELA CELERIDADE E A AFIRMAÇÃO DAS GARANTIAS CONSTITUCIONAIS}

Não é recente a preocupação dos operadores do Direito com a morosidade da prestação da tutela jurisdicional no Brasil e seu consequente efeito danoso à própria legitimidade e confiança dos jurisdicionados frente ao Poder Judiciário como agente pacificador de conflitos sociais.

Ao longo da vigência do Código de Processo Civil de 1973 (CPC/73), variadas foram as tentativas de amenizar este drama processual e melhorar a operatividade do sistema, por meio de sucessivas reformas processuais, sobretudo a partir dos anos 90 .

A guisa de curiosidade, cita-se os seguintes exemplos, dentre muitos outros: em 1994, a inclusão no sistema do instituto da antecipação de tutela (lei $\mathrm{n}^{\mathrm{o}} 8.952$, de 13 de dezembro de 1994); em 1995, a alteração do regime do agravo (lei $\mathrm{n}^{\circ}$ 9.139, de 30 de novembro de 1995) e a própria criação dos juizados especiais estaduais (lei no 9.099, de 26 de setembro de 1995); em 2001, a instituição dos juizados especiais federais (lei $\mathrm{n}^{\circ} 10.259$, de 12 de julho 2001); em 2004, a criação da Súmula Vinculante do Supremo Tribunal Federal (Emenda Constitucional n $n^{\circ}$ 45, de 30 de dezembro de 2004); em 2005 e 2006, as leis que alteraram a execução (lei ${ }^{\circ} 11.232$, de 22 de dezembro de 2005 e lei $n^{\circ} 11.382$, de 06 de dezembro de 2006); em 2007, a possibilidade de realização, por via administrativa, de separação e divórcio consensuais, inventário e partilha (lei n 11.441 , de 04 de janeiro de 2007); e, em 2008, o regime de julgamento conjunto de recursos especiais repetitivos no âmbito do Superior Tribunal de Justiça (lei no 11.672, de 08 de maio de 2008).

Noutro giro, ainda sob a égide do CPC/73, numerosas também foram as críticas da doutrina acerca deste tema.

Há quase duas décadas, José Rogério Cruz e Tucci (1997) já considerava o fator tempo como a mola propulsora da crise de efetividade do sistema judiciário brasileiro, 
lembrando a alusão feita por Elio Fazzalari ao referir-se à demora no processo como a “tormenta das tormentas” (FAZZALARI, apud CRUZ E TUCCI, 1997, p. 16).

Nessa mesma senda, José Roberto dos Santos Bedaque (2010), também de longa data, denuncia que o processo não vem desempenhando sua função de modo satisfatório, ao alertar que de nada adianta um processo dotado das características de segurança e justiça, se aliado a estas persiste a demora.

Daí se extrai que uma resposta jurisdicional em tempo razoável está intimamente atrelada à noção de efetividade do processo e da própria jurisdição estatal. Com efeito, a tão falada crise do sistema judicial brasileiro passa, antes de tudo, pela morosidade na prestação jurisdicional.

Em sua obra, Luiz Guilherme Marinoni, expondo acerca da dimensão do problema da demora processual e sua repercussão sobre a efetiva proteção do direito material, chega a afirmar que "[...] o autor com razão é prejudicado pelo tempo da justiça na mesma medida em que o réu sem razão é por ela beneficiado" (MARINONI, 2008, p. 188).

Com efeito, trata-se de uma preocupação que ultrapassa as fronteiras do direito processual brasileiro. Há muito, Francesco Carnelutti (1971) não via exageros em comparar o tempo no processo a um inimigo, contra o qual o juiz deve lutar sem tréguas.

Nesse sentido, não é outro o alerta de Mauro Cappelletti (2002, p. 191), para quem "[...] a demora excessiva é fonte de injustiça social, porque o grau de resistência do pobre é menor do que o grau de resistência do rico; esse último, e não o primeiro, pode, sem dano grave, esperar uma justiça lenta”.

Não é demais rememorar as contribuições de Michele Taruffo (2008) na ânsia de reverter a morosidade no sistema processual italiano, sobretudo defendendo a oralidade dos procedimentos, os ensinos de Roger Perrot (1998), denunciando a própria frustação da garantia do acesso à justiça no sistema processual francês, além da insatisfação alemã com a prestação jurisdicional (HEYDE, 1996).

Noutro giro, prosseguindo na análise da realidade brasileira, também sob o prisma econômico-financeiro a prolongação excessiva se revela danosa e também representa 
denegação da própria justiça, conforme atesta Oreste Nestor de Souza Laspro (1995, p. 114115):

\begin{abstract}
A prolongação do processo, com efeito, produz a elevação dos custos, fazendo com que, muitas vezes, a parte tenha gastos mais elevados em demandar do que em, simplesmente, renunciar a seu direito. Na verdade, a longa duração do processo configura, indiscutivelmente, uma denegação de justiça, provocando danos econômicos às partes, auxiliando aquele que demanda sem ter razão, constituindo verdadeira ofensa ao devido processo legal.
\end{abstract}

A doutrina contemporânea, por sua vez, permanece chamando a atenção para as vicissitudes que a morosidade pode causar em todo o sistema jurídico, inclusive na própria concepção de justiça, conforme alerta Marcelo Abelha Rodrigues (2013, p. 372-373):

\begin{abstract}
Numa sociedade em que a lepidez é marca indelével das relações comerciais e pessoais é certo que o processo não pode estar fora da realidade do seu tempo, sob pena de ser ele, o processo, um método inútil e inoperante de concessão de falsa justiça.
\end{abstract}

Destaca-se que mesmo a reforma promovida pela Emenda Constitucional no 45, em 2004, ao erigir o direito à tutela jurisdicional tempestiva ao status de garantia fundamental, no afã de concretizar, assim, o acesso a uma "ordem jurídica justa" que propicie "[...] a efetiva e tempestiva proteção contra qualquer forma de denegação da justiça [...]" (WATANABE, 1996, p. 20), não foi capaz, por si só, na prática, de pôr um termo a esta inquietação.

O enunciado constitucional, estampado no artigo $5^{\circ}$, LXXVIII, assim passou a determinar: "a todos, no âmbito judicial e administrativo, são assegurados a razoável duração do processo e os meios que garantam a celeridade de sua tramitação" (BRASIL, 1988).

Na verdade, mesmo antes de ser expressamente incorporado ao texto da Constituição Federal de 1988, a garantia de duração razoável do processo já havia sido contemplada em outros instrumentos normativos internacionais e regionais, com destaque para a Convenção Americana sobre Direitos Humanos, também denominada Pacto de San José da Costa Rica, do qual o Brasil é parte signatária. ${ }^{2}$

\footnotetext{
${ }^{2} \mathrm{O}$ artigo 8, ao tratar das garantias judiciais, estabelece que "toda pessoa tem direito a ser ouvida, com as devidas garantias e dentro de um prazo razoável, por um juiz ou tribunal competente [...]” (ORGANIZAÇÃO DOS ESTADOS AMERICANOS, 1969). Apesar de assinada em 22 de novembro de 1969, a Convenção Americana sobre Direitos Humanos só foi depositada pelo governo brasileiro em 1992, por meio do Decreto $\mathrm{n}^{\mathrm{O}}$ 678, de 6 de novembro de 1992.
} 
Como se sabe, não obstante a conquista obtida com a elevação do princípio da razoável duração do processo ao patamar de garantia fundamental, expressa na Constituição Federal, é no plano infraconstitucional que se dão os delineamentos concretos de tais garantias, isto é, por meio da lei infraconstitucional que é alcançada sua concretude.

Embalado por este espírito, portanto, o novo Código de Processo Civil (NCPC), recém sancionado (Lei $\mathrm{n}^{\circ}$ 13.105, de 16 de março de 2015), surgiu com o escopo de estabelecer um elo entre a legislação processual já desgastada e a Constituição Federal, sedimentando, na normativa infraconstitucional, muitas das garantias asseguradas na carta magna.

Em breve síntese, trata-se do fenômeno a que Hermes Zaneti Junior (2014, p. 8) denominou de "a constitucionalização do processo", consubstanciada na "necessidade de coerência prática, na vida jurídica, na aplicação de alguns preceitos" constitucionalmente assegurados.

Com efeito, o primeiro objetivo, dos cinco que orientaram os trabalhos da Comissão de Juristas encarregada de erigir o novel ordenamento processual, foi, justamente, o seguinte: "estabelecer expressa e implicitamente verdadeira sintonia fina com a Constituição Federal" (BRASIL, 2010).

Este claro propósito do novo código em realizar valores constitucionais é confirmado, também, pela leitura dos seguintes trechos da própria exposição de motivos do anteprojeto legislativo, assinada pela referida Comissão de Juristas, sob a presidência do Ministro Luiz Fux (BRASIL, 2010):

Na elaboração deste Anteprojeto de Código de Processo Civil, essa foi uma das linhas principais de trabalho: resolver problemas. Deixar de ver o processo como teoria descomprometida de sua natureza fundamental de método de resolução de conflitos, por meio do qual se realizavam valores constitucionais [...].

A coerência substancial há de ser vista como objetivo fundamental, todavia, e mantida em termos absolutos, no que tange à Constituição Federal da República. Afinal, é na lei ordinária e em outras normas de escalão inferior que se explicita a promessa de realização dos valores encampados pelos princípios constitucionais [...].

A necessidade de que fique evidente a harmonia da lei ordinária em relação à Constituição Federal da República fez com que se incluíssem no Código, expressamente, princípios constitucionais, na sua versão processual. Por 
outro lado, muitas regras foram concebidas, dando concreção a princípios constitucionais $[\ldots]$.

Nesse sentido, não foi mera obra do acaso que este escopo ficou estabelecido, expressamente, na redação final do artigo que inaugura o $\mathrm{NCPC},{ }^{-}$in verbis: "Art. $1^{\circ} \mathrm{O}$ processo civil será ordenado, disciplinado e interpretado conforme os valores e as normas fundamentais estabelecidos na Constituição da República Federativa do Brasil, observando-se as disposições deste Código" (BRASIL, 2015).

Dentre as garantias constitucionais com os quais o legislador infraconstitucional mais se mostrou zeloso em consolidar no NCPC, encontra-se, sem lampejo de dúvida, a razoável duração do processo.

Também da exposição de motivos do anteprojeto legislativo é possível extrair esta finalidade, bem como os danos que a morosidade na prestação jurisdicional causa aos jurisdicionados e ao próprio acesso à Justiça, conforme se vê dos seguintes trechos (BRASIL, 2010):

O novo Código de Processo Civil tem o potencial de gerar um processo mais célere, mais justo, porque mais rente às necessidades sociais e muito menos complexo.

Trata-se, portanto, de mais um passo decisivo para afastar os obstáculos para o acesso à Justiça, a que comumente se alude, isto é, a duração do processo, seu alto custo e a excessiva formalidade [...].

Levou-se em conta o princípio da razoável duração do processo. Afinal a ausência de celeridade, sob certo ângulo, é ausência de justiça.

Indo além, o artigo $6^{\circ}$ do NCPC confirma o dever processual de busca pela celeridade na prestação da tutela jurisdicional, ao dispor o seguinte: "Todos os sujeitos do processo devem cooperar entre si para que se obtenha, em tempo razoável, decisão de mérito justa e efetiva" (BRASIL, 2015).

Nesse passo, visando alcançar este propósito, merecem elogios as inúmeras medidas adotadas ao longo do novel código. Destacam-se, dentre outras, a criação do incidente de julgamento conjunto de demandas repetitivas (ou simplesmente incidente de resolução de demandas repetitivas, previsto no art. 976); a criação de maiores condições para realização de transação, com privilégio da mediação e da conciliação; e a possibilidade de concessão de 
tutela de evidência, em hipóteses em que as alegações da parte se revelem de juridicidade ostensiva, independentemente de perigo de demora (art. 311).

$\mathrm{Na}$ disciplina do subsistema recursal, outras medidas de grande impacto, visando à redução da morosidade, também foram adotadas, tais como a eliminação da figura do relator; o fim do duplo exame no juízo de admissibilidade, limitando-o ao órgão julgador; a ampliação das hipóteses de sustentação oral (art. 937), inclusive por videoconferência (art. 937, §4º); e o reforço e aprimoramento do regime de julgamento de recursos repetitivos, agora abrangendo a possibilidade de suspensão do procedimento das demais ações.

Ainda visando ao combate da morosidade na prestação da tutela jurisdicional, o NCPC trouxe mais reformas no subsistema recursal, com a limitação das hipóteses de cabimento do Agravo de Instrumento, apenas face às decisões interlocutórias expressamente determinadas, e a eliminação de duas espécies recursais anteriormente previstas no CPC/73.

Não obstante os notáveis objetivos almejados com tais modificações, não se pode perder de vista que a busca por conferir maior celeridade ao processo, atendendo aos reclames não só dos operadores do Direito mas também de toda sociedade, não pode ser conduzida a qualquer preço, não estando o NCPC indene de censuras caso tenha sobrepujado o escopo ora sob análise.

É o alerta que faz José Carlos Barbosa Moreira (2001, p. 232):

Para muita gente, na matéria, a rapidez constitui o valor por excelência, quiçá o único. Seria fácil invocar aqui um rol de citações de autores famosos, apostados em estigmatizar a morosidade processual. Não deixam de ter razão, sem que isso implique - nem mesmo, quero crer, no pensamento desses próprios autores - hierarquização rígida que não reconheça como imprescindível, aqui e ali, ceder o passo a outros valores. Se uma justiça lenta demais é decerto uma justiça má, daí não se segue que uma justiça muito rápida seja necessariamente uma justiça boa. O que todos devemos querer é que a prestação jurisdicional venha ser melhor do que é. Se para torná-la melhor é preciso acelerá-la, muito bem: não, contudo, a qualquer preço.

Nesse sentido, o questionamento que se faz é se tais medidas supressoras na legislação processual civil, representaram (ou representarão, no decorrer da vigência do novo código), de fato, medidas de acerto e coincidentes com o escopo anunciado, isto é, se, a partir de uma análise preliminar, alcançarão o efeito prático almejado com sua adoção, o que será esmiuçado no tópico seguinte. 


\section{AS MEDIdAS AdOTAdAS NO NOVO Código DE PROCESSO CIVIL: A SUPRESSÃO DE ESPÉCIES RECURSAIS E SUA REPERCUSSÃO}

Em resposta à necessidade de concretizar, na legislação processual, a garantia constitucional da razoável duração do processo, e partindo do pressuposto de que a “simplificação do sistema recursal leva a um processo mais ágil” (BRASIL, 2010), o NCPC, além de ter reduzido as hipóteses de cabimento do Agravo de Instrumento, eliminou duas espécies recursais previstas no $\mathrm{CPC} / 73$, quais sejam, o Agravo Retido e os Embargos Infringentes.

Contudo, antes de analisar a eficiência da adoção desta medida supressiva e seus possíveis reflexos no sistema recursal brasileiro, importa trazer à tona algumas considerações doutrinárias acerca da eliminação de recursos como instrumento apto a conferir celeridade à prestação jurisdicional.

Com efeito, o número de recursos previstos na legislação processual civil é objeto de reflexão e crítica, de longa data, na doutrina brasileira. Divagando a respeito deste tema, Teresa Arruda Alvim Wambier (2005, p. 249) ensina o seguinte:

\footnotetext{
Nosso sistema foi concebido a partir da suposição de que os recursos podem realmente servir à obtenção de uma justiça de melhor qualidade. Logo, há um limite para se reduzirem as dimensões do direito de recorrer, sob pena de se comprometer gravemente a garantia do acesso à justiça.

Por alguma razão, que não se sabe bem qual é, o nosso sistema recursal foi eleito para ser tratado como se fosse a causa de todos os males da jurisdição, inclusive e principalmente da morosidade dos processos. Sabe-se que este diagnóstico não é inteiramente verdadeiro.
}

Por sua vez, Marcelo Abelha Rodrigues (2013, p. 373) entende que “[...] não é o procedimento ordinário o algoz da demora processual e tampouco pode-se atribuir aos recursos essa culpa".

Na contramão destes entendimentos, contudo, Egas Moniz de Aragão (2006), após refletir sobre a existência de demasiados recursos no ordenamento jurídico brasileiro, defende que apenas três espécies recursais seriam suficientes para atender aos interesses da brevidade e da certeza da prestação jurisdicional, quais sejam, a apelação, o agravo e o extraordinário (gênero que inclui as espécies do recurso especial e recurso extraordinário). 
Sustenta sua tese, o referido autor, contudo, não sem antes fazer a seguinte advertência (MONIZ DE ARAGÃO, 2006, p. 21):

Todavia o combate à lentidão não se faz com supressão de vias de recorrer, mas com a aceleração generalizada da marca da máquina judiciária. Se esta, no seu todo, funciona devagar e ninguém se preocupa com o porquê, devagar continuará a funcionar, embora reduzido o número de recursos. Mesmo que se chegue à extinção absoluta, que deixará os tribunais entregues à ociosidade, perdurará a lentidão na primeira instância.

O que se vê, portanto, a partir destas prestigiosas reflexões doutrinárias, é que a morosidade na prestação da tutela jurisdicional não pode ser atribuída, exclusivamente, aos recursos. Todavia, não obstante esta evidente constatação, esta foi uma das medidas adotadas pelo NCPC, a fim de garantir uma prestação jurisdicional em tempo razoável, concretizando, desta feita, o texto constitucional.

Nesse diapasão, este estudo pretende demonstrar que a estratégia eleita, além de não contribuir, efetivamente para alcançar o resultado pretendido (conferir maior celeridade), pode, ao revés, acarretar danos ainda mais gravosos ao sistema, até mesmo alavancando os índices de morosidade a patamares superiores aos já existentes.

\subsection{AS LIMITAÇÕES DAS HIPÓTESES DE CABIMENTO DO AGRAVO DE INSTRUMENTO}

Nesse sentido, a primeira medida sob exame é a limitação das hipóteses de cabimento do Agravo de Instrumento. Em última análise, esta medida significa, também, uma supressão recursal, eis que reduz os casos em que o referido recurso pode ser interposto.

Da leitura do artigo 1.015 do NCPC, nota-se, de pronto, que o Agravo de Instrumento somente poderá ser manejado contra determinadas decisões interlocutórias proferidas ao longo do processo, elencadas no rol de incisos do referido artigo. Corresponde, com efeito a uma "[...] tarifação dos casos em que é cabível o recurso de agravo de instrumento [...]" (BUENO, 2015, p. $653)$.

Contudo, considerando que eventuais equívocos na prolatação de decisões interlocutórias são inevitáveis, por diversas razões, inclusive ante o exacerbado volume de processos a cargo dos magistrados, e tendo em conta que, por vezes, é necessário sua correção 
imediata sob pena de causar prejuízos irreparáveis à parte, seguramente o obstáculo processual será vencido por meio da adoção de outras medidas elencadas ao longo do próprio código de processo civil, bem como previstas em leis extravagantes, quando apresentarem-se hipóteses de pronunciamentos judiciais não sujeitos a agravo de instrumento, pela nova disciplina.

A título exemplificativo, Cássio Scarpinella Bueno (2015) apresenta situações tais como decisão que aceita a intervenção do litisconsorte ou que aceite o desmembramento, hipóteses não previstas como agraváveis de instrumento.

Sendo assim, a menos que haja uma interpretação (doutrinária e jurisprudencial) ampliativa das hipóteses indicadas nos incisos do artigo 1.015 do NCPC, corre-se o sério risco de se ver, no cotidiano forense civil, um reforço dos já conhecidos "pedidos de reconsideração", meio informal de impugnação das decisões judiciais, cujo incremento pode trazer como efeito mais atraso na marcha processual.

Indo além, a redução aqui tratada pode ainda motivar um emprego generalizado do Mandado de Segurança contra ato judicial, como sucedâneo recursal.

Tendo em vista a irrecorribilidade imediata das decisões interlocutórias em matéria eleitoral, sabe-se que, no âmbito dessa justiça especializada, o Mandado de Segurança é o meio de impugnação por excelência, com o qual as partes e juízes estão habituados e convivem bem.

Todavia, cabe o questionamento se o subsistema do processo civil (sobretudo o aparato forense, estrutural e de recursos humanos) está preparado para receber uma possível enxurrada de Mandados de Segurança combatendo decisões interlocutórias não previstas no rol do artigo 1.015 .

Importante lembrar que o Mandado de Segurança possui prioridade de julgamento frente às demais ações, o que pode contribuir para a morosidade do julgamento dos demais recursos, causando efeito contrário àquele pretendido pelo NCPC.

Mesmo porque, por força do $\S 1^{\circ}$ do artigo 20 da Lei n ${ }^{\circ} 12.016$, de 07 de agosto de 2009, em instância recursal, os Mandados de Segurança "[...] deverão ser levados a julgamento na primeira sessão que se seguir à data em que forem conclusos ao relator” (BRASIL, 2009). 
Sendo assim, o cenário que surge tende a ser o seguinte: o meio de impugnação que se mostrará mais adequado para corrigir eventuais equívocos perpretados em decisões interlocutórias não previstas no rol do artigo 1.015 do NCPC deixa de ser o Agravo de Instrumento e passa a ser outro, sendo que este ainda possui prioridade de julgamento frente às demais ações, inclusive nos tribunais.

Ao que parece, esta medida acabará contribuindo para o aumento do número de processos a serem examinados pela instância revisora, mesmo porque retira a possibilidade de o prolator da decisão recorrida, conhecendo as razões de irresignação do recorrente, possa rever seu entendimento, tal como ocorreria com o manejo do Agravo de Instrumento.

\subsection{SUPRESSÃO DO AGRAVO RETIDO}

De outra parte, a discussão aqui exposta ganha ainda mais relevo diante da extinção do agravo na forma retida. É que por meio dessa supressão recursal promovida com o advento do NCPC, cabe à parte prejudicada pelas interlocutórias não agraváveis de instrumento, se não fizer uso das medidas anunciadas linhas atrás, pleitear seu reexame em sede de preliminar de apelação, nas razões ou nas contrarrazões (art. 1.009, $\S 1^{\circ}$ do NCPC).

O que se nota é que a técnica de julgamento permaneceu, em última análise, inalterada, haja vista que as razões de irresignação acostadas ao Agravo Retido também somente eram objeto de análise pela instância revisora quando da apreciação de eventual recurso de Apelação e desde que o recorrente assim solicitasse, em sede de preliminar do apelo.

Com efeito, a supressão do Agravo Retido manteve o mesmo momento de julgamento das decisões interlocutórias de que se trata adotado no sistema anterior (CPC/73), tendo, contudo, realizado alteração significativa a respeito do momento da impugnação de tais decisões.

Isto porque, com o advento do NCPC, tais decisões interlocutórias, não agraváveis de instrumento, não ficam sujeitas à preclusão. Em outros termos, extraiu-se do caderno processual civil brasileiro a preclusão imediata das questões decididas no curso do processo em primeiro grau de jurisdição, na forma estabelecida pelo $\S 1^{\circ}$ do artigo 1.009 do NCPC. 
Na verdade, a preclusão (isto é, o momento de impugnação) foi protraída para a fase recursal. É nesse sentido que se diz que o NCPC adotou um sistema de "preclusão elástica", conceito cunhado por Piero Calamandrei (1999), muito embora empregado em outra dimensão ${ }^{3}$, mas bem adaptado por Zulmar Duarte de Oliveira Junior (2011) para a situação ora analisada.

Em síntese, a nova feição esculpida pelo NCPC permite a retomada, em sede recursal, de uma questão há muito já decidida em primeiro grau, haja vista a ausência de preclusão imediata, como se viu.

Nessa perspectiva, teme-se que o recurso de Apelação, abarrotado de preliminares, acabe se transformando em um verdadeiro amontoado de irresignações pontuais, isto é, em um instrumento de impugnação que abarque inúmeras questões anteriormente já decididas e cuja rediscussão se pretende realizar, muito após sua ocorrência.

Uma solução para amenizar os possíveis danos à celeridade processual, seria a adoção, no processo civil, do chamado protesto antipreclusivo. Trata-se de mecanismo bem utilizado no âmbito do processo do trabalho, em que também vige o princípio da irrecorribilidade imediata das decisões interlocutórias, por meio do qual é garantido às partes a futura discussão e possível revisão, em sede recursal, de tais pronunciamentos judiciais.

Desta forma, na primeira oportunidade após a prolatação da decisão interlocutória não agravável de instrumento, a parte interessada protestaria por sua revisão, evitando, assim, que se operasse a preclusão. Caso contrário, isto é, omitindo-se a parte, a questão resolvida por meio da decisão interlocutória quedar-se-ia preclusa, impedindo-se ulterior revisão.

Além de fazer operar sobre as questões "não protestadas" a preclusão imediata, funcionaria, o protesto antipreclusivo, como verdadeiro delimitador das questões eventualmente submetidas à revisão da instância recursal, evitando a sobrecarga do recurso de Apelação com a ressurreição de questões há muito já decididas ao longo do curso do processo.

Inclusive, tal medida valorizaria a oralidade e a simplificação dos atos processuais, em nada comprometendo a celeridade, muito pelo contrário, tampouco representando o retorno do abolido agravo retido.

\footnotetext{
${ }^{3}$ Piero Calamandrei (1999) se referia à flexibilização da preclusão das deduções de mérito no sistema processual civil italiano.
} 
Como registro, vale mencionar que, no andamento do projeto legislativo do NCPC, chegou a ser proposta a inclusão, ao novo regramento processual, do instituto do protesto antipreclusivo, em redação assim então sugerida: "[...] A impugnação prevista no $\S 1^{\circ}$ [de decisões não sujeitas a agravo de instrumento] pressupõe a prévia apresentação de protesto específico contra a decisão no primeiro momento que couber à parte falar nos autos, sob pena de preclusão [...]" (BRASIL, 2014).

Não obstante, esta proposta não prevaleceu no texto normativo final, de modo que sem o protesto antipreclusivo, toda e qualquer questão decidida no curso do processo, em primeiro grau, poderá, se não for hipótese de agravo de instrumento, ser reinvocada no âmbito recursal.

Sem dúvidas, há a ameaça concreta de que a supressão do agravo retido acabe contribuindo, em sentido diametralmente oposto ao escopo pretendido, para que o andamento processual caminhe com mais vagar.

\subsection{Supressão dos Embargos Infringentes}

Indo além, outra grande alteração trazida ao subsistema recursal com o advento do NCPC, e talvez a que mais desperta críticas, foi a abolição dos Embargos Infringentes e a criação de uma nova técnica processual de julgamento em sua substituição, na hipótese de haver resultado não unânime.

A iniciativa legislativa está intimamente ligada à busca pelo aprimoramento da qualidade das decisões judiciais com a ampliação da colegialidade, da discussão em torno da matéria, ao lado da garantia da segurança jurídica e da eliminação de interpretações jurídicas divergentes em um mesmo tribunal, tudo sem prejuízo ao contraditório, garantia que também está assegurado na nova técnica, inclusive diante da possibilidade de sustentação oral.

Aqui já é necessário fazer a primeira advertência, a respeito da busca cega pelo consenso jurisprudencial como sinônimo de verdade ou, mesmo, de justiça. Com efeito "a unanimidade, assim como o consenso, não é (nem nunca foi) sinônimo de justiça das decisões" (STRECK; HERZL, 2015, p. 6). 
A nova técnica de julgamento trazida pelo NCPC, insculpida no artigo 942 do NCPC, prevê que quando não houver unanimidade no julgamento em segunda instância, haverá o prosseguimento automático da votação, em mesma sessão, caso os novos julgadores componham o mesmo órgão fracionário e estejam presentes, ou, se não for possível, em sessão subsequente, por convocação de novos julgadores, sempre em número suficiente para alterar o resultado proclamado.

Se a intenção legislativa era reduzir o volume de recursos e de trabalho no âmbito dos tribunais e, com isso, atingir maior celeridade nos julgamentos, parece, contudo, que a nova técnica, além de não atingir o fim destinado, pode gerar efeito adverso.

Isto porque, se de um lado, houve a abolição da espécie recursal, de outro, a nova técnica de julgamento criada ampliou as hipóteses de cabimento da rediscussão da matéria em divergência, uma vez que prevê a complementação do julgamento face a decisões não unânimes não apenas em sede de recurso de apelação e de ações rescisórias julgadas procedentes, como no sistema do CPC/73, mas agora também em agravos de instrumento (interpostos contra decisão interlocutória que julgar parcialmente o mérito).

Noutro giro, também se verifica mais uma extensão do cabimento na medida em que a nova técnica não mais exige que o acórdão proferido em julgamento do recurso de apelação tenha reformado a sentença de primeiro grau, como ocorria com o sistema dos abolidos Embargos Infringentes. De acordo com o NCPC, para que se dê a continuação do julgamento é suficiente que o julgamento do recurso de apelação tenha por resultado uma decisão não unânime, inclusive se mantiver os termos da sentença apelada.

Afora estas questões, que por si sós revelam a gravidade desta nova técnica de julgamento estabelecida com o fim de dar celeridade ao processo, tem-se em mente, ainda, outros elementos que também revelam que a medida adotada pelo NCPC pode caminhar na contramão de sua pretensão inaugural.

Com efeito, observando-se o comando imperativo do artigo 942 do NCPC ("[...] o julgamento terá prosseguimento [...]", grifo nosso), extrai-se que se trata de uma técnica não apenas automática, mas sobretudo obrigatória, o que tende a contribuir para o incremento do volume de processos nos tribunais. 
Por certo, a supressão dos Embargos Infringentes e sua transformação em técnica de julgamento aboliu a necessidade de novas razões recursais e de nova distribuição para novo relator, como ocorria no sistema anterior, o que, segundo muitos de seus defensores, poderia contribuir para a tão almejada celeridade.

Contudo, é preciso dizer que excluiu-se também, do recorrente, o próprio atributo da voluntariedade, isto é, sua livre manifestação de vontade em ver a matéria objeto da divergência reexaminada pelo colegiado, ou não.

Nesse sentido, não se pode negar que se trata de um direito do jurisdicionado de buscar, ou não, a obtenção de uma prestação jurisdicional mais qualificada, mediante correção da decisão que lhe foi desfavorável. Com efeito, não se pode fechar os olhos para as situações em que, ainda que a decisão não tenha lhe sido totalmente favorável, é mais vantajoso para a parte acatá-la, do que socorrer-se, mais uma vez, da tutela jurisdicional, em sede de recurso, e permanecer na expectativa de um direito que já poderia lhe ser assegurado, mesmo que em parte.

Portanto, se de um lado, houve a abolição de uma espécie recursal, por outro, sua transformação em um expediente incidental obrigatório, por determinação legal, é capaz de trazer consequências ainda mais gravosas à marcha processual em tempo razoável.

Indo além, como se sabe, os julgamentos dos recursos não se resumem às hipóteses de procedência ou improcedência das alegações das partes recorrentes, sendo comum hipóteses outras, como votos no sentido da extinção do processo sem resolução de mérito, isto é, criando situações em que coexistem votos em mais de duas direções.

Assim, caso a divergência no resultado abarque cenários como tais, não é possível afirmar, com precisão, quantos novos julgadores seriam suficientes para garantir a possibilidade de inversão do resultado inicial que prevaleceu.

Trata-se de uma questão que não apresenta solução imediata, seja pelo silêncio do NCPC, seja considerando os próprios limites subjetivos de composição dos tribunais brasileiros e de seus respectivos órgãos fracionários. 
O que se viu, das observações acima apontadas, é que as medidas supressoras adotadas pelo NCPC são, na verdade, insuficientes para combater o mal da morosidade na prestação jurisdicional brasileira, podendo até mesmo causar efeito contrário ao pretendido.

Talvez porque, as circunstâncias que giram em torno da lentidão processual ultrapassam as barreiras de uma mera reforma processual, sobretudo recursal, atingindo outras deficiências jurisdicionais, inclusive estruturais e de recursos humanos, ou, ainda, passando pela própria formação excessivamente contenciosa dos acadêmicos de Direito no Brasil.

Paralelamente a isto, urge que sejam adotadas medidas outras, dentre as quais uma punição mais efetiva à litigância de má-fé e um maior rigor na aplicação de multas para recursos eminentemente protelatórios, para corrigir as imperfeições da demora na prestação jurisdicional.

Tudo isto sem contar que "[...] nada mais nada menos do que $95 \%$ do total de processos dos 100 maiores litigantes nacionais são do setor público (estadual, federal e municipal), bancos e telefonias" (RODRIGUES, 2013, p. 374), e, mesmo assim, o sistema processual ainda convive com mecanismos como o instituto da remessa necessária e os prazos diferenciados, em prestígio àqueles que mais movimentam a máquina judiciária no país mas, certamente, na contramão da pretendida celeridade.

\section{CONSIDERAÇÕES FINAIS}

O acesso a uma justiça célere e efetiva é um anseio de todos. Contudo, não é crível que se admita a adoção de medidas que, malgrado buscarem atingir este nobre escopo, acabem não apenas não o alcançando como também trazendo efeitos contrários, contribuindo para o incremento da morosidade da prestação jurisdicional.

O presente artigo iniciou-se tratando da incapacidade do sistema processual em superar o dilema da demora da justiça mesmo diante de sucessivas reformas, apresentando críticas doutrinárias a respeito desta inquietação.

Prosseguiu na abordagem acerca do movimento contemporâneo em prol da realização, nas normas processuais, dos valores e garantias constitucionais, dentre as quais se destaca a 
razoável duração do processo, ambiente no qual foi erigido o novo Código de Processo Civil brasileiro (Lei no 13.105, de 16 de março de 2015).

Em seguida, foi possível constatar que, muito embora o alerta de muitos estudiosos processualistas no sentido de não ser o sistema recursal a origem da morosidade na prestação jurisdicional, o novo diploma processual optou por adotar medidas de cunho restritivo no cabimento de recursos, com o fulcro de alcançar celeridade.

Como se viu, o novo código de ritos, além de limitar as hipóteses de cabimento do Agravo de Instrumento a determinadas situações previstas em um rol, extinguiu o Agravo Retido e os Embargos Divergentes.

No que tange a tais medidas restritivas perpetradas pelo novo código, especificamente, identificou-se a possibilidade real de as mesmas não só gerarem um aumento do número de processos a serem examinados pela instância revisora, como também contribuírem para que o andamento processual caminhe com mais lentidão.

Portanto, não obstante se tratar de um esforço intelectual de prever uma provável ocorrência dos desdobramentos processuais aqui anunciados, é forçoso concluir, a partir das análises contidas no presente estudo, pelo caráter temerário de tais medidas, adotadas com o escopo de tornar mais célere a prestação jurisdicional.

\section{REFERÊNCIAS}

BEDAQUE, José Roberto dos Santos. Efetividade do processo e técnica processual. 3 ed. São Paulo: Malheiros, 2010.

BRASIL. Constituição (1988). Constituição da República Federativa do Brasil. Brasília: Senado Federal, 1988.

. Lei $\mathrm{n}^{\mathbf{0}}$ 12.016, de 07 de agosto de 2009. Disciplina o mandado de segurança individual e coletivo e dá outras providências. Brasília: Senado Federal, 2009.

- Exposição de Motivos. Comissão de Juristas Responsável pela Elaboração de Anteprojeto de Código de Processo Civil. Brasília: Senado Federal, 2010. Disponível em: <http://www.senado.gov.br/senado/novocpc/pdf/anteprojeto.pdf >. Acesso em: 15 jun. 2015. 
. Substituto da Câmara dos Deputados ao Projeto de Lei do Senado $n^{\circ}$ 166, de

2010. Código de Processo Civil. Texto inicial. Brasília: Senado Federal, 2014. Disponível em: $<$ http://www.senado.gov.br/atividade/materia/detalhes.asp?p_cod_mate=116731>. Acesso em: 15 jun. 2015.

. Código de Processo Civil (2015). Lei no 13.105, de 16 de março de 2015. Código de processo civil. Brasília: Senado Federal, 2015.

BUENO, Cassio Scarpinella. Novo código de processo civil anotado. São Paulo: Saraiva, 2015 .

CALAMANDREI, Piero. Direito processual civil: estudos sobre o Processo Civil. Campinas: Bookseller, 1999.

CAPPELLETTI, Mauro; GARTH, Bryant. Acesso à justiça. Porto Alegre: Fabris, 2002.

CARNELUTTI, Francesco. Diritto e processo. Buenos Aires: EJEA, 1971.

CRUZ E TUCCI, José Rogério. Tempo e processo. São Paulo: Revista dos Tribunais, 1997.

HEYDE, Wolfgang. La jurisdicción. In: BENDA, Ernst et al. Manual de derecho constitucional. Madrid: Marcial Pons, 1996.

LASPRO, Oreste Nestor de Souza. Duplo grau de jurisdição no direito processual civil. São Paulo: Revista dos Tribunais, 1995.

MARINONI, Luiz Guilherme. Teoria geral do processo. 3. ed. São Paulo: Revista dos Tribunais, 2008.

MONIZ DE ARAGÃO, Egas Dirceu. Demasiados recursos?. Revista de Processo, São Paulo, ano 31, n. 136, p. 9-31, jun. 2006.

MOREIRA, José Carlos Barbosa. O futuro da justiça: alguns mitos. Revista de Processo, São Paulo, v. 102, p. 228-237, abr./jun. 2001.

OLIVEIRA JUNIOR, Zulmar Duarte de. Preclusão elástica no novo CPC. Revista de Informação Legislativa, Brasília, ano 48, n. 190, abr./jun. 2011. 
ORGANIZAÇÃO DOS ESTADOS AMERICANOS. Convenção americana sobre direitos humanos (1969). Disponível em: < http://www.cidh.oas.org >. Acesso em: 10 jul. 2015.

PERROT, Roger. O processo civil francês na véspera do século XXI. Revista Forense, Rio de Janeiro, v. 94, n. 342, p. 161-168, abr./maio/jun. 1998.

RODRIGUES, Marcelo Abelha. Prolongamento da litispendência, recursos e duração (ir)razoável do processo: a quem interessa retardar a tutela jurisdicional? In: DE OLIVEIRA, Bruno Silveira et al. (Coord.). Recursos e a duração razoável do processo. Brasília: Gazeta Jurídica, 2013.

STRECK, Lênio Luiz; HERZL, Ricardo Augusto. O que é isto - os novos embargos infringentes? Uma mão dá e a outra. Revista Consultor Jurídico, 13 de jan. 2015. Disponível em: <www.conjur.com.br>. Acesso em: 09 jul. 2015.

TARUFFO, Michele. Orality and writing as factors of efficiency in civil litigation. In: CARPI, Frederico; ORTELLS, Manuel (Org.). Oralidad y escritura en un proceso civil eficiente. València: Universitat de València, 2008.

WATANABE, Kazuo. Tutela antecipatória e tutela específica das obrigações de fazer e não fazer. In: TEIXEIRA, Sálvio de Figueiredo (Coord.). Reforma do código de processo civil. São Paulo: Saraiva, 1996.

WAMBIER, Teresa Arruda Alvim. Restrições indevidas ao direito de recorrer. Revista de Processo, São Paulo, ano 30, n. 130, p. 249-251, dez. 2005.

ZANETI JUNIOR, Hermes. A constitucionalização do processo: o modelo constitucional da justiça brasileira e as relações entre processo e constituição. 2. ed. São Paulo: Atlas, 2014. 